\title{
Effect of sunflower-seed oil and linseed oil on tissue lipid metabolism, gene expression, and milk fatty acid secretion in Alpine goats fed maize silage-based diets
}

\author{
L. Bernard, ${ }^{*}$ M. Bonnet, ${ }^{*}$ C. Leroux, ${ }^{*}$ K. J. Shingfield, $†$ and Y. Chilliard ${ }^{* 1}$ \\ *INRA, UR1213 Herbivores, Site de Theix, F-63122 Saint-Genès-Champanelle, France \\ †MTT Agrifood Research Finland, Animal Production Research, Jokioinen, FIN-31600, Finland
}

\begin{abstract}
Lipid in the diet is known to enhance milk fat secretion and alter milk fatty acid composition in lactating goats. In the current experiment, the contribution of peripheral tissue and mammary gland lipid metabolism to changes in milk fat composition from plant oils was examined. Fourteen Alpine goats in midlactation were used in a $3 \times 3$ Latin square design with 28 -d experimental periods. Treatments comprised maize silage-based diets containing no additional oil (M), sunflower-seed oil (MSO; $6.1 \%$ of diet DM), or linseed oil (MLO; $6.2 \%$ of diet DM). Compared with the control, milk yield was greater in goats fed MSO (3.37 and $3.62 \mathrm{~kg} / \mathrm{d}$, respectively), whereas MLO enhanced milk fat content $(+3.9 \mathrm{~g} / \mathrm{kg})$, resulting in a $14 \%$ increase in milk fat secretion. Both MSO and MLO increased milk lactose secretion by 12 and $8 \%$, respectively, compared with M. Relative to the control, plant oils decreased C10 to C16 secretion (32 and 24\%, respectively, for MSO and MLO) and enhanced C18 output in milk (ca. 110\%). Diets MSO and MLO increased cis-9 18:1 secretion in milk by 25 and $31 \%$, respectively, compared with $\mathrm{M}$. The outputs of trans-11 18:1 and cis-9, trans-11 18:2 in milk were increased 8.34- and 6.02-fold for MSO and 5.58- and 3.71-fold for MLO compared with M, and MSO increased trans-10 18:1 and trans-10, cis12 18:2 secretion. Plant oils decreased milk fat cis-9 14:1/14:0; cis-9 16:1/16:0; cis-9 18:1/18:0; and cis-9, trans-11 18:2/trans-11 18:1 concentration ratios but had no effect on mammary stearoyl-CoA desaturase mRNA or activity. Furthermore, changes in milk fatty acid secretion were not associated with alterations in mammary acetyl-CoA carboxylase mRNA and activity, abundance of mRNA encoding for lipoprotein lipase and fatty acid synthase, or malic enzyme and
\end{abstract}

Received January 19, 2009.

Accepted August 9, 2009.

${ }^{1}$ Corresponding author: chilliar@clermont.inra.fr glycerol-3-phosphate dehydrogenase activity in mammary tissue. Mammary lipoprotein lipase activity was increased with MSO relative to MLO. Treatments had no effect on glucose-6-phosphate dehydrogenase, malic enzyme, glycerol-3-phosphate dehydrogenase activity, or mRNA abundance and/or activity of lipoprotein lipase, acetyl-CoA carboxylase, fatty acid synthase, and stearoyl-CoA desaturase in liver or adipose tissue. In conclusion, inclusion of sunflower-seed oil and linseed oil in maize silage-based diets alters milk fatty acid secretion in goats via mechanisms independent of changes in mammary, hepatic, or adipose tissue lipogenic gene expression. Furthermore, data provided indications that the regulation of mammary lipogenic responses to plant oils on starch-rich diets differs between the caprine and bovine.

Key words: lactating goat, plant oil, lipogenic gene expression, milk fatty acid secretion

\section{INTRODUCTION}

Milk fat is an important determinant of milk nutritional quality, with certain saturated fatty acids (FA; mainly 12:0, 14:0, and 16:0) possibly exerting negative effects when consumed in excess and others (4:0, anteiso-15:0, cis-9 18:1, 18:3n-3) having potentially positive effects on human health (Parodi, 2005). Furthermore, there is evidence in animal models that cis-9, trans-11, the major isomer of conjugated linoleic acid (CLA) in ruminant milk, exhibits anticarcinogenic and antiatherogenic properties (Wahle et al., 2004). It has been well established that nutrition is a major factor determining the concentration and secretion of specific FA in ruminant milk (Chilliard et al., 2007; Shingfield et al., 2008).

Fatty acids secreted in milk originate from de novo synthesis in the mammary gland and from triacylglycerides (TAG) and NEFA in arterial blood. Milk fat synthesis is known to involve the coordinated activity of several lipogenic enzymes, but the effect of nutri- 
tion on the regulation of mammary lipogenesis is not well established. Lipoprotein lipase (LPL), acetyl-CoA carboxylase (ACC), fatty acid synthase (FAS), and stearoyl-CoA desaturase (SCD) are considered key lipogenic enzymes, and therefore, research has been directed toward the identification of factors regulating the activity of these enzymes in ruminant species.

Studies on the nutritional regulation of mammary lipogenic gene expression in lactating cows have, in the main, involved investigations examining the response to diets containing high proportions of concentrates and/ or plant oils and marine lipids (Piperova et al., 2000; Ahnadi et al., 2002; Peterson et al., 2003; Harvatine and Bauman, 2006) that induce milk fat depression (MFD). Experiments inducing maximal or close to maximal reductions in milk fat yield have provided evidence that specific biohydrogenation intermediates formed during ruminal metabolism of dietary unsaturated FA alter mammary lipid metabolism and gene expression. Data in lactating goats on the role of nutrition on mammary metabolism and expression of genes encoding for key lipogenic enzymes are scarce, with measurements being confined to studies examining the effect of plant oils on grass hay-based diets (Bernard et al., 2005a,b, 2009a). Furthermore, indirect comparisons have identified species-specific differences in milk fat secretion and composition responses to plant oils between the goat and cow (Chilliard et al., 2003, 2007).

The current experiment examined the effect of sunflower-seed oil or linseed oil on mammary, adipose, and liver lipid metabolism and gene expression during established lactation in goats fed maize silage-based diets to understand possible mechanisms regulating mammary lipogenesis on starch-rich diets and assess the possible contribution of peripheral tissues to changes in milk fatty acid secretion. Plant oils were selected as sources of 18:2n- 6 and 18:3n-3 to test the following hypotheses: 1) a proportion of polyunsaturated FA contained in plant oils and escaping metabolism in the rumen have direct effects on mammary tissue in the goat based on evidence that polyunsaturated FA either depress (Clarke, 2001) or enhance (Ailhaud et al., 2006) lipogenic gene expression in rodent adipose tissues and 2) specific intermediates formed during biohydrogenation of polyunsaturated FA in the rumen are involved in the regulation of lipogenic gene expression, lipogenic enzyme activity, and milk fat secretion (Harvatine and Bauman, 2006). Furthermore, the experiment was designed to generate data allowing the relationship between measurements of mRNA abundance and activity of key lipogenic enzymes to be examined, offering insight into the level of regulation of lipogenic gene expression in the lactating mammary gland.

\section{MATERIALS AND METHODS}

\section{Animals and Diets}

All experimental procedures were approved by the Animal Care Committee of INRA in accordance with the Use of Vertebrates for Scientific Purposes Act of 1985. Fourteen multiparous $(3.3, \mathrm{SD}=1.1)$ Alpine goats in midlactation (70 DIM, SD $=7.0$ ) were offered 3 experimental diets according to a $3 \times 3$ Latin square design with 28-d experimental periods and 4 or 5 animals per group. Each experimental period comprised a 21-d adaptation to treatments and a 7-d sampling period. Goats were housed in a metabolism unit in individual stalls with continuous access to water and were milked at 0800 and $1600 \mathrm{~h}$. Experimental diets (Table 1) were formulated to meet energy and protein requirements (INRA, 1989). Diets were based on maize silage offered ad libitum and a concentrate mixture supplemented with no additional oil (M), $130 \mathrm{~g} / \mathrm{d}$ of sunflower-seed oil (MSO; Auvergne Trituration, Lezoux, France), or 130 $\mathrm{g} / \mathrm{d}$ of linseed oil (MLO; SA Vandeputte, Mouscron, Belgium) offered as 2 equal meals at 0830 and $1630 \mathrm{~h}$. Procedures used to recruit experimental animals have been reported previously (Bernard et al., 2009b).

\section{Measurements and Sampling}

Feed intakes, chemical composition of experimental diets, and milk yield were determined for each experimental period according to sampling protocols and analytical procedures outlined elsewhere (Bernard et al., 2009b). Samples of milk were collected from all goats over 4 consecutive milkings starting at $0800 \mathrm{~h}$ on d 21 of each experimental period for fat, CP, and lactose analysis. Milk fat, CP, and lactose were determined in samples treated with preservative (potassium bichromate, Merck, Fontenay-Sous-Bois, France) by near infrared spectroscopy (AOAC, 1997). Unpreserved samples of milk were also collected over 2 consecutive milkings starting at $0800 \mathrm{~h}$ on d 22 of each experimental period, stored at $-20^{\circ} \mathrm{C}$, composited according to yield, and submitted for the determination of FA composition (Bernard et al., 2009b) and sodium, potassium, and chloride concentrations (AOAC, 1997). An index of milk osmotic pressure (simplified molecular constant) was calculated (Mathieu and Ferré, 1914) as simplified molecular constant $=[$ lactose $(\mathrm{g} / \mathrm{L})+11.9$ sodium chloride $(\mathrm{g} / \mathrm{L})] \times 1.06$, based on the isotonic equilibrium that exists between lactose and chloride concentrations. Live weight of experimental animals was measured at the start and end of each experimental period.

Blood samples were collected on d 23 of each experimental period at $0730 \mathrm{~h}$. Samples from the jugular vein 
Table 1. Ingredient and chemical composition of experimental diets

\begin{tabular}{|c|c|c|c|}
\hline \multirow[b]{2}{*}{ Item } & \multicolumn{3}{|c|}{ Treatment $^{1}$} \\
\hline & $\mathrm{M}$ & MSO & MLO \\
\hline \multicolumn{4}{|l|}{ Ingredients (\% of DM) } \\
\hline Maize silage & 38.8 & 45.5 & 45.2 \\
\hline Sunflower-seed oil ${ }^{2}$ & 0.0 & 6.1 & 0.0 \\
\hline Linseed oil ${ }^{3}$ & 0.0 & 0.0 & 6.2 \\
\hline Rolled barley & 24.9 & 11.8 & 11.8 \\
\hline Dehydrated sugar beet pulp & 24.4 & 16.3 & 16.3 \\
\hline Soybean meal & 11.9 & 20.3 & 20.5 \\
\hline Mineral-vitamin $\operatorname{mix}^{4}$ & 0.5 & 0.5 & 0.5 \\
\hline \multicolumn{4}{|c|}{ Chemical composition (\% of DM) } \\
\hline $\mathrm{OM}$ & 94.5 & 88.5 & 88.3 \\
\hline $\mathrm{CP}$ & 14.0 & 17.1 & 17.1 \\
\hline $\mathrm{NDF}$ & 31.0 & 29.5 & 29.4 \\
\hline $\mathrm{ADF}$ & 17.4 & 17.1 & 17.1 \\
\hline Starch & 28.0 & 22.1 & 22.0 \\
\hline Ether extract & 2.0 & 8.2 & 8.4 \\
\hline
\end{tabular}

${ }^{1}$ Refers to maize silage-based diets containing no additional oil (M), $6.1 \%$ of DM of sunflower-seed oil (MSO), or $6.2 \%$ of DM of linseed oil (MLO).

${ }^{2}$ Sunflower-seed oil contained (g/100 g of fatty acids) 16:0 (6.6), 18:0 (3.8), cis-9 18:1 (17.5), 18:2n-6 (70.4), and 18:3n-3 (0.1).

${ }^{3}$ Linseed oil contained (g/100 g of fatty acids) 16:0 (5.8), 18:0 (3.6), cis-9 18:1 (18.9), 18:2n-6 (15.6), and 18:3n-3 (49.0).

${ }^{4}$ Mineral-vitamin supplement (Usine d'Ussel, Murat, France) declared as containing $(\mathrm{g} / \mathrm{kg}) \mathrm{Ca}(240), \mathrm{P}(60), \mathrm{Mg}(50), \mathrm{Na}(15), \mathrm{Zn}(7), \mathrm{Mn}$ (6), DL- $\alpha$-tocopherol (0.3), retinol (0.2), and cholecalciferol (0.002).

were collected into evacuated collection tubes (Venoject, C.M.L., Nemours, F-77792, France) containing potassium-EDTA. Once collected, blood samples were centrifuged $\left(1,500 \times g\right.$ for $15 \mathrm{~min}$ at $\left.4^{\circ} \mathrm{C}\right)$, and plasma was analyzed for insulin and metabolite concentrations (Bernard et al., 2005b).

On d 24-25 of periods 1 and 2, mammary biopsies were obtained after morning milking for tissue RNA extraction using sterile Trucut needles (CE Sherwood Medical, Northern Ireland) according to the manufacturer's instructions. Approximately 20-25 mg of tissue was taken, rinsed in $0.9 \%$ saline sterile solution, inspected to verify tissue homogeneity, and snap frozen in liquid nitrogen. Samples were stored at $-80^{\circ} \mathrm{C}$ before RNA extraction. Collection of tissue biopsies resulted in minimal bleeding, and milk appeared normal after 1 to 3 subsequent milkings. During this period, extreme care was taken during manual milking to remove possible blood clots lodged in the glands. No intramammary infections or loss of milk production were encountered following mammary tissue biopsies.

At the end of the experiment, corresponding to $\mathrm{d}$ 24-25 of the third experimental period, goats were slaughtered after morning milking. Immediately before slaughter, animals were milked to remove most of the milk in the mammary glands. Immediately after death, samples of mammary, liver, and perirenal adipose tissues were collected under sterile conditions, frozen in liquid nitrogen, and stored at $-80^{\circ} \mathrm{C}$ until RNA extraction and enzyme assays. Samples of mammary tissue were analyzed for SCD activity immediately after collection. Samples of perirenal adipose tissue were also collected immediately after slaughter, stored at $37^{\circ} \mathrm{C}$, fixed with osmium tetraoxide, and isolated in $8 \mathrm{M}$ urea for the determination of adipocyte volume (Chilliard et al., 1991).

\section{Enzyme Assays}

Lipoprotein lipase (EC 3.1.1.34) activity was measured in samples of milk, mammary, and perirenal adipose tissues (Faulconnier et al., 1994). Activity of FAS (EC 2.3.1.85), glycerol-3-phosphate dehydrogenase (G3PDH; EC 1.1.1.8), glucose-6-phosphate dehydrogenase (G6PDH; EC 1.1.1.49), and malic enzyme (MLE; EC 1.1.1.40) was determined in perirenal adipose and mammary tissues (Chilliard et al., 1991). Samples of mammary tissue were also analyzed for ACC (EC 6.4.1.2) and SCD (EC 1.14.99.5) activity (Bernard et al., 2005b).

\section{RNA Isolation and Real-Time Reverse Transcription-PCR}

Total RNA was isolated from samples of mammary tissue using the RNeasy mini kit (Qiagen Inc., Courtaboeuf, France), and total RNA in liver was extracted using the NucleoSpin RNA II kit (Macherey Nagel Inc., Hoerdt, France). For the extraction of total RNA in adipose tissue, the procedure of Bonnet et al. (2000) was used. Deoxyribonucleic acid contamination was removed by DNase I treatment (amplification grade, Invitrogen, Cergy-Pontoise, France) before cDNA synthesis. Integrity and concentration of RNA and real time reverse transcription-PCR were assessed as described previously (Bernard et al., 2005b). Abundance of targeted gene (LPL, ACC, FAS, SCD) transcripts were expressed as the mRNA copy number relative to the cyclophilin A (housekeeping gene) to account for variations in RNA integrity, RNA quantification, and cDNA synthesis.

\section{Statistical Analysis}

Measurements of DM intake, milk production, milk composition, FA secretion in milk, and mammary mRNA abundance were subjected to analysis of variance for a $3 \times 3$ Latin square design using the general linear models procedure of SAS (SAS Institute, Cary, $\mathrm{NC}$ ) with a model that included the effects of treatment, period, and goat. Treatment means were compared using the least squares means procedure (SAS Institute) 
Table 2. Effect of linseed oil or sunflower-seed oil in the diet on DMI, milk yield, milk composition, and energy and protein balance in goats

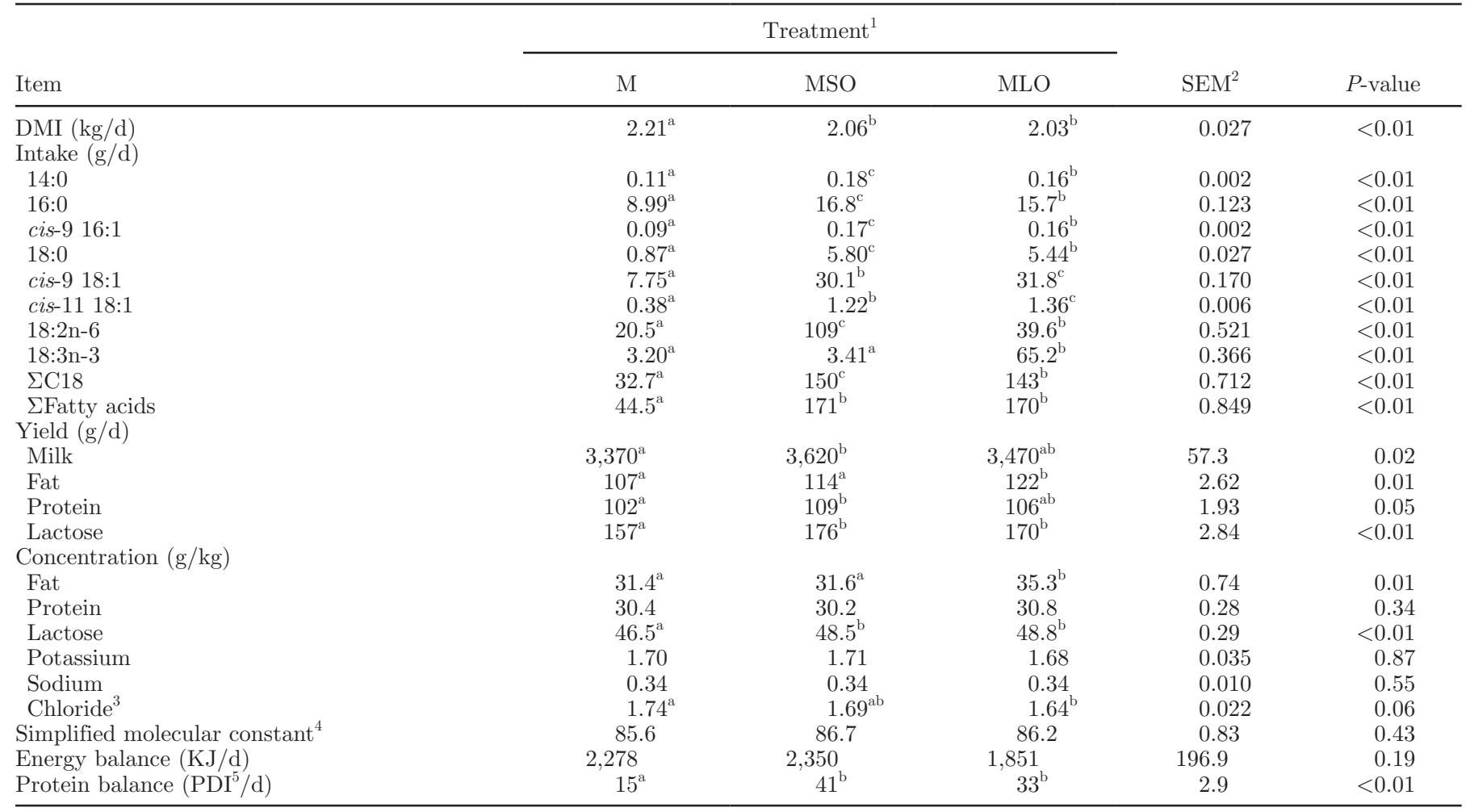

${ }^{\mathrm{a}-\mathrm{c}}$ Means within a row with different superscripts differ $(P<0.05)$.

${ }^{1}$ Refers to maize silage-based diets containing no additional oil (M), $6.1 \%$ of DM of sunflower-seed oil (MSO), or $6.2 \%$ of DM of linseed oil (MLO).

${ }^{2}$ Standard error of the mean for $\mathrm{n}=42$; error degrees of freedom $=24$.

${ }^{3}$ For milk chloride concentration, $P=0.06$.

${ }^{4}$ Calculated as [lactose $(\mathrm{g} / \mathrm{L})+11.9$ sodium chloride $\left.(\mathrm{g} / \mathrm{L})\right] \times 1.06$.

${ }^{5} \mathrm{PDI}=$ protein digestible in the intestine.

with differences declared significant at $P<0.05$. Measurements of enzyme activity and mRNA abundance in samples of mammary, hepatic, and adipose tissue collected at slaughter were evaluated statistically using the nonparametric Wilcoxon $U$ test. Treatment effects were considered significant at $P<0.05$.

\section{RESULTS}

\section{Diet Composition}

Maize silage was of high quality, both in terms of nutritive value and fermentation characteristics, and had the following composition $(\mathrm{g} / \mathrm{kg}$ of $\mathrm{DM}$, unless otherwise stated): DM (g/kg fresh weight) $308, \mathrm{OM}$ 949, CP 86, NDF 412, ADF 243, starch 327, and total FA content 29. The mean forage:concentrate ratios (on a DM basis) for treatments M, MSO, and MLO were 39:61, 45:55, and 45:55, respectively. By design, 18:2n-6 was the major FA ingested on M and MSO (20.5 and $109.2 \mathrm{~g} / \mathrm{d}$, respectively), and 18:3n-3 was the predomi- nant FA supplied by MLO $(65.2 \mathrm{~g} / \mathrm{d})$. Experimental diets supplied 32.7, 150, and $143 \mathrm{~g} / \mathrm{d}$ of total C18 FA for M, MSO, and MLO, respectively (Table 2).

\section{Animal Performance}

Even though plant oils in the diet decreased $(P=$ 0.001) DM intake, energy and protein balance were positive for all experimental treatments (Table 2). Relative to the control, MSO enhanced milk yield $(+250$ $\mathrm{g} / \mathrm{d} ; P=0.02)$ and milk protein yield $(+7 \mathrm{~g} / \mathrm{d} ; P=$ $0.05)$, whereas MLO increased milk fat yield $(+15 \mathrm{~g} / \mathrm{d}$; $P=0.01)$ and milk fat content $(+3.9 \mathrm{~g} / \mathrm{kg} ; P=0.01)$. Inclusion of sunflower-seed oil and linseed oil in the diet increased $(P=0.001)$ milk lactose concentration (mean responses of 2.0 and $2.3 \mathrm{~g} / \mathrm{kg}$, respectively) but had no effect $(P>0.05)$ on milk potassium and sodium concentrations (Table 2). However, MLO tended $(P=$ $0.06)$ to decrease milk chloride concentration. As expected, the simplified molecular constant was similar among treatments (Table 2). 
Table 3. Effect of linseed oil or sunflower-seed oil in the diet on plasma insulin and metabolite concentrations, milk lipoprotein lipase activity, and postmilking lipolysis in goats

\begin{tabular}{|c|c|c|c|c|c|}
\hline Item & \multicolumn{3}{|c|}{ Treatment $^{1}$} & $\mathrm{SEM}^{2}$ & $P$-value \\
\hline Glucose $(\mathrm{m} M)$ & 3.56 & 3.61 & 3.67 & 0.054 & 0.34 \\
\hline NEFA $(\mathrm{m} M)$ & $0.18^{\mathrm{a}}$ & $0.23^{\mathrm{ab}}$ & $0.27^{\mathrm{b}}$ & 0.024 & 0.05 \\
\hline Total cholesterol (mM) & $2.48^{\mathrm{a}}$ & $4.49^{\mathrm{b}}$ & $3.50^{\mathrm{c}}$ & 0.104 & $<0.01$ \\
\hline Phospholipid $(\mathrm{m} M)$ & $1.74^{\mathrm{a}}$ & $2.42^{\mathrm{c}}$ & $2.21^{\mathrm{b}}$ & 0.005 & $<0.01$ \\
\hline 3 -Hydroxybutyrate $(\mathrm{m} M)$ & $0.44^{\mathrm{a}}$ & $0.38^{\mathrm{b}}$ & $0.38^{\mathrm{b}}$ & 0.016 & 0.05 \\
\hline Urea $(\mathrm{m} M)$ & $5.49^{\mathrm{a}}$ & $8.33^{\mathrm{b}}$ & $7.83^{\mathrm{b}}$ & 0.260 & $<0.01$ \\
\hline Lipoprotein lipase $(\mathrm{nmol} / \mathrm{min}$ per $\mathrm{mL})$ & 501.5 & 353.1 & 465.3 & 44.48 & 0.07 \\
\hline Lipolysis $^{3}$ & 0.43 & 0.37 & 0.35 & 0.039 & 0.41 \\
\hline
\end{tabular}

${ }^{\mathrm{a}-\mathrm{c}}$ Means within a row with different superscripts differ $(P<0.05)$.

${ }^{1}$ Refers to maize silage-based diets containing no additional oil (M), $6.1 \%$ of DM of sunflower-seed oil (MSO), or $6.2 \%$ of DM of linseed oil (MLO).

${ }^{2}$ Standard error of the mean for $\mathrm{n}=42$; error degrees of freedom $=24$.

${ }^{3}$ Lipolysis determined as milk fat cis-9 18:1 equivalents ( $\mathrm{g} / 100 \mathrm{~g}$ of fat) after storage at $4^{\circ} \mathrm{C}$ for $34 \mathrm{~h}$ postmilking.

\section{Plasma Metabolites and Milk Lipoprotein Lipase Activity}

Treatments had no effect $(P>0.05)$ on plasma glucose or insulin concentrations (Table 3). Compared with the control, MLO increased $(P=0.05)$ plasma NEFA concentrations. Furthermore, plant oils in the diet enhanced $(P=0.001)$ total cholesterol, phospholipid, TAG, and urea concentrations and decreased plasma acetate $(P=0.001)$ and BHBA content $(P=$ 0.05 ; Table 3$)$. Milk LPL activity tended to decrease $(P$ $=0.07$ ) with treatment MSO compared with $\mathrm{M}$, and the extent of lipolysis during storage postmilking was comparable across treatments (Table 3 ).

\section{Mammary, Adipose Tissue, and Liver Lipid Metabolism}

Treatments had no effect $(P>0.05)$ on the abundance of mRNA encoding for LPL, ACC, and/or FAS, and SCD in mammary (Table 4), liver, or perirenal adipose tissue (Table 5). Furthermore, plant oils had no effect $(P>0.05)$ on LPL, FAS, G6PDH, MLE, and G3PDH activity in perirenal adipose tissue (Table 6), with the exception of a trend $(P=0.09)$ toward greater LPL activity for MSO compared with the control.

In the mammary gland, MSO increased $(P=0.04)$ LPL activity relative to MLO, and MLO enhanced ( $P$ $=0.02) \mathrm{G} 6 \mathrm{PDH}$ activity compared with treatment $\mathrm{M}$ (Table 6). Relative to the control, MSO enhanced $(P=$ 0.04) mammary FAS activity. In contrast, supplementing the diet with plant oils had no effect $(P>0.05)$ on MLE, ACC, and G3PDH activity (Table 6) or mammary mRNA abundance encoding for LPL, ACC, FAS, and SCD (Table 4).

\section{Milk Fatty Acid Secretion}

Plant oils in the diet decreased $(P<0.001)$ milk secretion of 10:0-14:0, 16:0, and cis-9 16:1 responses that were associated with an increase $(P<0.001)$ in the output of 18:0, cis-9 18:1, trans- $\Delta^{11-13}-18: 1$, Ecis18:1, Strans-18:1, and $\Sigma$ C18 in milk (Table 7). Relative increases in milk fat trans-11 18:1 secretion were greater for $\mathrm{MSO}(+734 \%)$ than for $\mathrm{MLO}(+458 \%)$. Lipid supplements also increased $(P<0.001)$ milk fat cis-9, trans-11 CLA; trans-7, cis-9 CLA; trans-8, cis10 CLA; trans-9, trans-11 CLA; and trans-10, trans-12 CLA secretion (Table 7). Inclusion of sunflower-seed oil in the diet resulted in specific increases $(P<0.05)$ in milk trans-10 18:1 and trans-10, cis-12 CLA output, whereas supplementing the diet with linseed oil resulted in a specific increase $(P<0.001)$ in milk trans-11, cis13 CLA yield. Relative increases in milk cis-9, trans-11

Table 4. Effect of linseed oil or sunflower-seed oil in the diet on mRNA abundance encoding for lipoprotein lipase (LPL), acetyl-CoA carboxylase (ACC), fatty acid synthase (FAS), and stearoyl-CoA desaturase (SCD) in mammary tissue of goats

\begin{tabular}{lccccc}
\hline & \multicolumn{3}{c}{ Treatment $^{1}$} & & \\
\cline { 2 - 4 } mRNA & $\mathrm{M}$ & MSO & MLO & SEM $^{2}$ & $P$-value \\
\hline LPL & 7.15 & 8.34 & 8.07 & 0.733 & 0.44 \\
ACC & 1.08 & 0.99 & 1.12 & 0.071 & 0.62 \\
FAS & 3.61 & 3.81 & 3.48 & 0.312 & 0.58 \\
SCD & 21.1 & 19.6 & 17.6 & 1.942 & 0.36 \\
\hline
\end{tabular}

${ }^{1}$ Refers to maize silage-based diets containing no additional oil (M), $6.1 \%$ of DM of sunflower-seed oil (MSO), or $6.2 \%$ of DM of linseed oil (MLO). Levels of mRNA expressed in arbitrary units determined as abundance relative to cyclophilin A mRNA and multiplied by 100.

${ }^{2}$ Standard error of the mean for $\mathrm{n}=42$; error degrees of freedom $=$ 24. 
Table 5. Effect of linseed oil or sunflower-seed oil in the diet on mRNA abundance encoding for lipoprotein lipase (LPL), fatty acid synthase (FAS), acetyl-CoA carboxylase (ACC), and stearoyl-CoA desaturase (SCD) in perirenal adipose and hepatic tissues of goats

\begin{tabular}{lccc}
\hline & \multicolumn{3}{c}{ Treatment $^{1}$} \\
\cline { 2 - 4 } mRNA & $\mathrm{M}(\mathrm{n}=5)$ & MSO $(\mathrm{n}=5)$ & MLO $(\mathrm{n}=4)$ \\
\hline Perirenal adipose tissue & $212.5 \pm 42.8$ & $199.5 \pm 64.5$ & $212.8 \pm 25.3$ \\
LPL & $132.6 \pm 38.1$ & $87.9 \pm 24.4$ & $97.0 \pm 12.8$ \\
FAS & $7.46 \pm 1.59$ & $6.02 \pm 1.88$ & $5.14 \pm 2.00$ \\
SCD & & & $0.017 \pm 0.002$ \\
Liver & $0.015 \pm 0.004$ & $0.012 \pm 0.003$ & $0.111 \pm 0.026$ \\
LPL & $0.171 \pm 0.021$ & $0.119 \pm 0.015$ & $0.317 \pm 0.080$ \\
ACC & $0.286 \pm 0.059$ & $0.347 \pm 0.108$ & $4.41 \pm 1.10$ \\
FAS & $5.48 \pm 0.37$ & $4.16 \pm 0.84$ & \\
SCD &
\end{tabular}

${ }^{1}$ Refers to maize silage-based diets containing no additional oil (M), $6.1 \%$ of DM of sunflower-seed oil (MSO), or $6.2 \%$ of DM of linseed oil (MLO). Levels of mRNA expressed in arbitrary units determined as abundance relative to cyclophilin A mRNA and multiplied by 100. Values are means \pm SE.

CLA output were greater for MSO $(+502 \%)$ than for MLO $(+271 \%)$. Similarly, increases in trans-8, cis-10 CLA; trans-9, trans-11 CLA; and trans-10, trans-12 CLA secretion in milk were greater for MSO than for MLO. Plant oils also decreased $(P<0.05)$ milk fat cis-9 14:1/14:0; cis-9 16:1/16:0; cis-9 18:1/18:0; and cis-9, trans-11 CLA/trans-11 18:1 concentration ratios compared with the control (Table 7). Total C18 FA from the diet were apparently transferred into milk with mean efficiencies of 82,37 , and $39 \%$ for $\mathrm{M}$, MSO, and MLO, respectively (Table 7).

\section{DISCUSSION}

\section{DMI and Milk Production and Composition}

Plant oils resulted in a marginal reduction in DM intake that might have arisen from a possible effect of plant oils on the palatability of the diet or the hypophagic effects of unsaturated FA in the diet altering ruminal fermentation characteristics, a release of gut hormones, and/or lipid oxidation in the liver (Allen, 2000). Lesser concentrations of acetate and BHBA in plasma with plant oils in the diet are consistent with

Table 6. Effect of linseed oil or sunflower-seed oil in the diet on lipoprotein lipase (LPL), acetyl-CoA carboxylase (ACC), fatty acid synthase (FAS), glucose-6-phosphate dehydrogenase (G6PDH), malic enzyme (MLE), stearoyl-CoA desaturase (SCD), and glycerol-3-phosphate dehydrogenase (G3PDH) activity in mammary and perirenal adipose tissues of goats

\begin{tabular}{lccc}
\hline & \multicolumn{3}{c}{ Treatment $^{1}$} \\
\cline { 2 - 4 } Item & $\mathrm{M}(\mathrm{n}=5)$ & MSO $(\mathrm{n}=5)$ & MLO $(\mathrm{n}=4)$ \\
\hline Mammary gland $^{2}$ & & \\
LPL & $12.6 \pm 2.55^{\mathrm{ab}}$ & $18.0 \pm 1.92^{\mathrm{b}}$ & $10.4 \pm 1.6^{\mathrm{a}}$ \\
ACC & $6.9 \pm 1.14$ & $7.7 \pm 2.05$ & $6.7 \pm 0.55$ \\
FAS & $59 \pm 10.6^{\mathrm{a}}$ & $99 \pm 9.12^{\mathrm{b}}$ & $97 \pm 15.3^{\mathrm{ab}}$ \\
G6PDH & $108 \pm 6.7^{\mathrm{a}}$ & $171 \pm 30.4^{\mathrm{ab}}$ & $148 \pm 12.5^{\mathrm{b}}$ \\
MLE & $1.5 \pm 0.33$ & $1.7 \pm 0.25$ & $1.4 \pm 0.18$ \\
SCD & $0.094 \pm 0.0115$ & $0.078 \pm 0.0140$ & $0.105 \pm 0.0188$ \\
G3PDH & $55.8 \pm 9.43$ & $67.8 \pm 9.53$ & $52.3 \pm 6.0$ \\
Perirenal adipose tissue & & & \\
LPL & $87 \pm 4.1$ & $178 \pm 48.4$ & $100 \pm 18.9$ \\
FAS & $278 \pm 53.5$ & $421 \pm 155.3$ & $222 \pm 42.1$ \\
G6PDH & $877 \pm 135.8$ & $1,144 \pm 302.0$ & $643 \pm 128.3$ \\
MLE & $212 \pm 39.3$ & $344 \pm 116.3$ & $191 \pm 51.6$ \\
G3PDH & $6,322 \pm 955.3$ & $10,258 \pm 3,461.9$ & $6,167 \pm 787.9$ \\
\hline
\end{tabular}

${ }^{\mathrm{a}, \mathrm{b}}$ Means within a row with different superscripts differ $(P<0.05)$.

${ }^{1}$ Refers to maize silage-based diets containing no additional oil (M), $6.1 \%$ of DM of sunflower-seed oil (MSO), or $6.2 \%$ of DM of linseed oil (MLO).

${ }^{2}$ Values represent mean activity $\pm \mathrm{SE}$ expressed in $\mathrm{nmol} / \mathrm{min}$ per $\mathrm{mg}$ of protein.

${ }^{3}$ Values represent mean activity $\pm \mathrm{SE}$ expressed in $\mathrm{nmol} / \mathrm{min}$ per $10^{6}$ adipocytes. Adipocyte volume determined in samples collected at slaughter, maintained at $37^{\circ} \mathrm{C}$, fixed with osmium tetraoxide, and isolated in 8 $M$ urea. 
previous studies in lactating goats (Bernard et al., 2005b; 2009a) and point toward total ruminal VFA production being decreased by sunflower-seed oil and linseed oil supplements in goats fed maize silage-based diets.

Milk production and composition responses to linseed oil (Table 2) are consistent with previous studies in goats (Chilliard et al., 2003) demonstrating that inclusion of plant oils in the diet typically increases milk fat content but has no effect on milk yield. In contrast, sunflower-seed oil had no effect on milk fat concentra- tions, which might be related to one of several factors. It is possible that interactions between the starch-rich basal diet and lipid-rich-in 18:2n-6 sunflower-seed oil enhanced the formation of specific biohydrogenation intermediates in the rumen that served to limit or minimize the lipogenic effects of plant lipids typically reported in goats (Chilliard et al., 2007). Previous studies have shown that feeding cows maize silage-based diets containing $328 \mathrm{~g} / \mathrm{kg}$ of DM of starch and $50 \mathrm{~g} /$ $\mathrm{kg}$ of DM of sunflower-seed oil (Roy et al., 2006) or offering high-concentrate diets with a starch content

Table 7. Effect of linseed oil or sunflower-seed oil in the diet on the secretion of major fatty acids in milk, including specific isomers of conjugated linoleic acid (CLA), milk fat $\Delta^{9}$-desaturase ratios, and apparent transfer of C18 fatty acids in goats

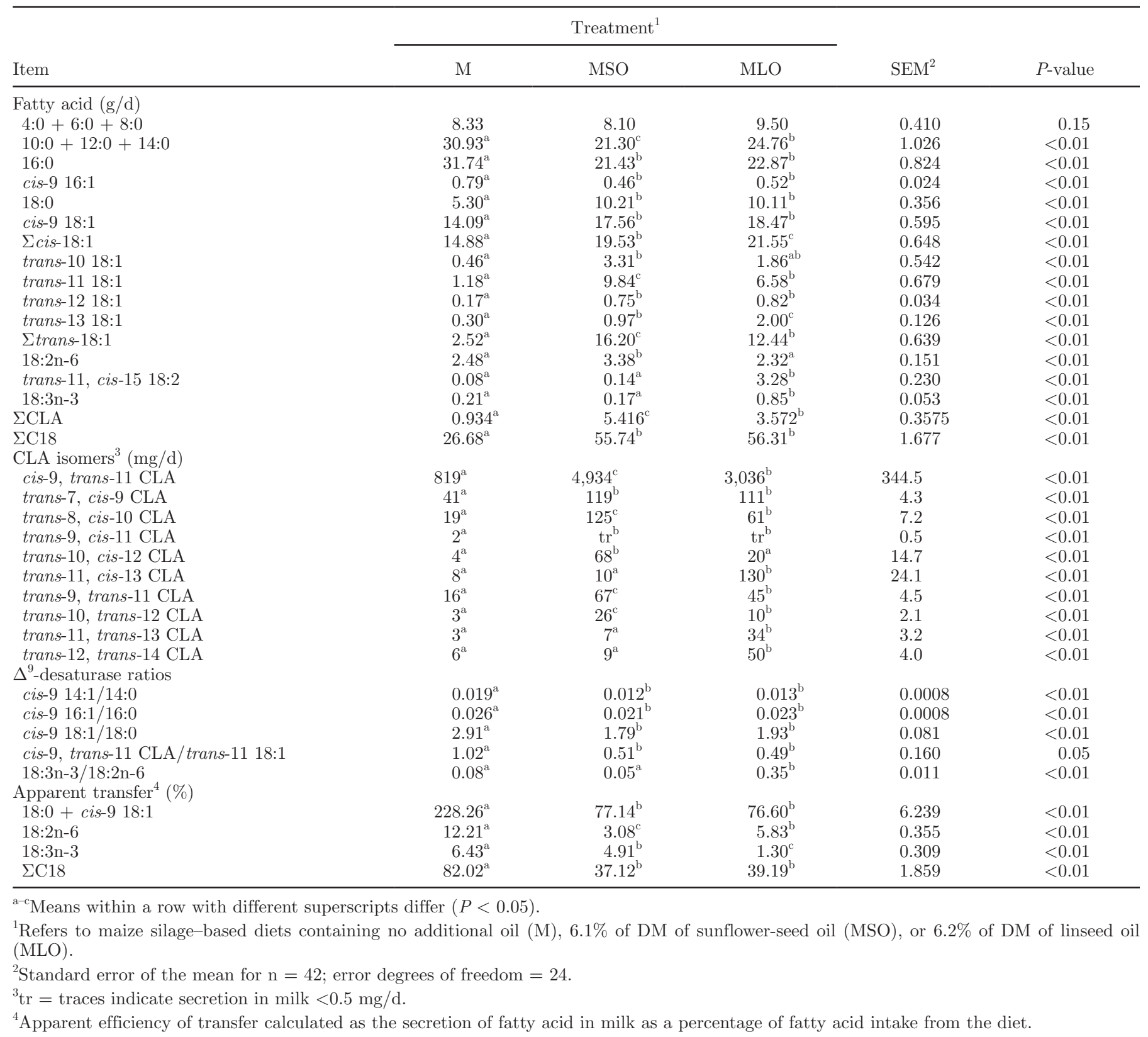


of $220 \mathrm{~g} / \mathrm{kg}$ of DM and supplemented with linseed oil (Loor et al., 2005) resulted in 40 and $21 \%$ decreases in milk fat secretion, respectively, with the implication that the caprine mammary gland is less sensitive to the antilipogenic effects of ruminal biohydrogenation intermediates compared with the bovine. Furthermore, plasma insulin concentrations of goats in this experiment $(25 \mu \mathrm{IU} / \mathrm{mL}$; Table 3$)$ were greater than value of $17 \mu \mathrm{IU} / \mathrm{mL}$ determined in lactating cows fed diets containing comparable amounts of starch as those used in the current study (Loor et al., 2005). Comparisons between ruminant species indicate that the circulating concentrations of insulin measured in goats are within the range reported for cows fed diets causing MFD, with the corollary that insulin has no direct involvement in the absence of MFD in the caprine.

It is also possible that a concomitant increase in milk yield accounts for the lack of an increase in milk fat percentage with MSO compared with the control. The increase in milk yield with sunflower-seed oil was associated with a greater yield and concentration of lactose in milk in agreement with previous studies in goats (Chilliard et al., 2003) and consistent with the role of lactose in the regulation of milk osmolarity (Cant et al., 1993). An absence of variation of the simplified molecular constant in response to plant oils in the diet is in accordance with the isotonic equilibrium that is known to exist between lactose and chloride concentrations in milk.

Indirect comparisons with studies in cows fed a diet of comparable composition to MSO (Roy et al., 2006) suggest that plant oils elicit a larger increase in milk lactose concentrations in goats and highlight the possibility of differences in the regulation of mammary lactose synthesis between ruminant species.

\section{Adipose and Liver Lipid Metabolism}

Plant oils in the diets had no effect on mRNA abundance encoding for LPL, ACC, FAS, and SCD in the liver. Even though lipogenic capacity is known to vary between liver and adipose tissues in ruminant species (Vernon, 1980), SCD mRNA abundance in the liver and adipose tissue of goats was of similar magnitude in this experiment, in accordance with previous findings in sheep (Ward et al., 1998), suggesting that the liver might contribute to the $\Delta^{9}$-desaturation of absorbed FA. Studies in steers have also provided evidence that the SCD is active in the liver (Chang et al., 1992). Hepatic FAS and LPL mRNA abundance was extremely low, consistent with earlier studies in the goat (Bernard et al., 2009a) and the low activity of FAS, extent of FA synthesis de novo, and very low-density lipoprotein uptake in the ruminant liver relative to that in adi- pose tissue and the lactating mammary gland (Vernon, 1980). Overall, current data offered no support that the responses to plant oils in the diet were mediated via changes in lipogenic gene expression and/or enzyme activity in hepatic or perirenal adipose tissue, which is in agreement with previous studies in goats during mid- (Bernard et al., 2005b, 2009a) or late (Bernard et al., 2005a) lactation. An absence of altered lipogenic activity in adipose tissue is consistent with treatments having minimal effects on energy balance or plasma insulin and glucose concentrations, which are known to be involved in the regulation of lipogenesis (Vernon, 1980). These findings are in contrast with experiments with cows in established lactation demonstrating a reduction of lipogenic activity of perirenal or subcutaneous adipose tissue in response to postruminal infusions of rapeseed oil (Chilliard et al., 1991) or dietary fat (McNamara et al., 1995), despite the greater net energy balance in animals receiving lipid supplements (Gagliostro and Chilliard, 1991; Harrison et al., 1995). Furthermore, infusion of rapeseed oil had no effect on plasma glucose concentrations but lessened circulating concentrations of insulin and enhanced growth hormone levels (Gagliostro et al., 1991), hormonal responses that might account, at least in part, for the differences in lipogenic responses of adipose tissue to plant oils between cows and goats. Because of the limited number of observations made in this experiment, it is not possible to draw definitive conclusions on the level of regulation of gene expression in caprine adipose tissue. Studies in cows have shown that the expression of genes involved in anabolic pathways is decreased during lactation, leading to the conclusion that a reduction in tissue lipogenesis is primarily the result of lowered enzyme synthesis (Sumner et al., 2007).

Comparison of enzyme activities between tissues as a ratio with G6PDH highlights the substantially greater activity of G3PDH and MLE in perirenal adipose tissue compared with the mammary gland. In the case of G3PDH, the greater activity might reflect the use of glucose as an energy substrate for TAG synthesis and storage and the formation of glycerol 3-phosphate being derived, in the main, from the action of G3PDH due to the absence of glycerol kinase in adipose tissue (Vernon, 1980). In contrast, 2-monoglyceride and free glycerol uptake serve as the main sources of glycerol for TAG synthesis in the mammary gland, thus limiting the requirement for G3PDH in the synthesis of glycerol 3-phosphate and allowing glucose to be spared for lactose synthesis (Vernon et al., 1987). Tissuespecific differences in MLE activity are in line with recent studies indicating the inability to detect this protein in the bovine mammary proteome (Beddek et al., 2008). 


\section{Milk Fatty Acid Secretion and Mammary Metabolism}

Plant oils decreased the output of medium-chain FA (10:0 to 16:0) in milk, consistent with a decrease in mammary FA synthesis de novo and previous studies examining the effect of forages, oilseeds, and oil supplements on mammary lipogenesis in the goat and cow (Chilliard et al., 2007). However, indirect comparisons point toward a lesser decrease in milk 10:0 to 16:0 secretion in goats on the MSO treatment of $-32 \%$ compared with a reduction of $-69 \%$ in cows offered a diet of comparable composition (Roy et al., 2006). In the current experiment, changes in milk FA secretion were not accompanied by significant alterations in G6PDH, MLE, or G3PDH activity or ACC and FAS mRNA abundance and/or activity, findings that are in agreement with studies in goats fed other plant lipids (Bernard et al. 2005a,b) or sunflower-seed oil and linseed oil at the same level of inclusion (Bernard et al., 2009a) in diets based on grass hay. Analysis of ACC and FAS gene expression data demonstrated a positive association between mRNA and enzyme activity for $\operatorname{ACC}(\mathrm{r}=0.70, \mathrm{n}=14, P=0.01$; Figure 1$)$ and to a lesser extent for FAS $(\mathrm{r}=0.59, \mathrm{n}=14, P=0.05)$, suggesting that regulation at the level of transcription occurs, at least for these 2 genes in the ruminant mammary gland, in addition to probable posttranslational regulation events (Bernard et al., 2008). Treatments MSO and MLO resulted in an unexpected increase in mammary FAS or G6PDH activity. It is possible that these observations are related to the inherent variation in the activity of these enzymes between animals, rather than reflecting biologically significant responses to lipid in the diet per se.

The majority of studies on the nutritional regulation of lipogenic gene expression and enzyme activity in the lactating cow have involved examining responses to lowforage diets (Peterson et al., 2003); rations containing soybean oil (Piperova et al., 2000), fish oils (Ahnadi et al., 2002), marine lipids, and plant oils (Harvatine and Bauman 2006); or postruminal or intravenous infusion of trans-10, cis-12 CLA (Baumgard et al., 2000; Harvatine and Bauman, 2006) that also induce MFD. Under these circumstances, substantial reductions in milk $\mathrm{C} 4$ to $\mathrm{C} 16 \mathrm{FA}$ secretion of between -30 and $-59 \%$ have been associated with a decrease in mammary ACC and FAS mRNA abundance and/or activity. In contrast, both current and previous studies in goats (Bernard et al., 2005a,b, 2009a) fed grass hay or maize silage-based diets supplemented with formaldehyde-treated linseed, soybeans, oleic-rich sunflower-seed oil, sunflower-seed oil, or linseed oil have indicated that 18 to $32 \%$ decreases in the secretion of FA synthesized de novo occurred in the absence of altered mammary expression

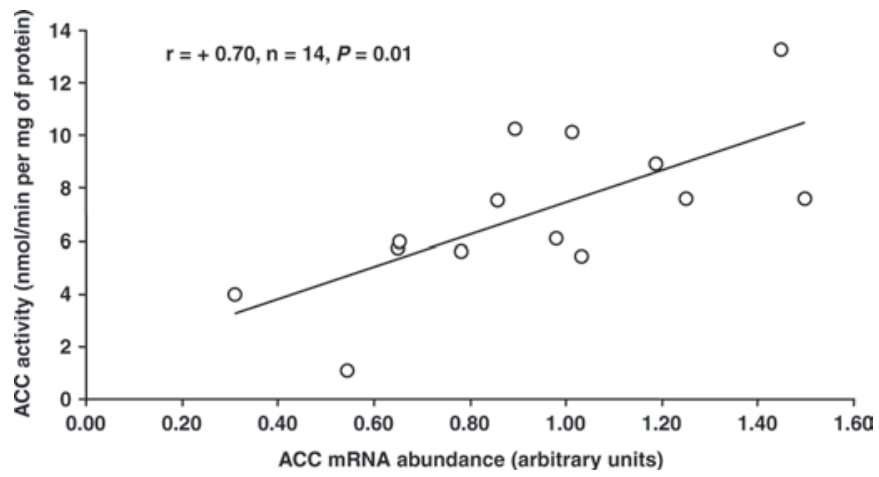

Figure 1. Relationship between acetyl-CoA carboxylase (ACC) mRNA abundance and activity in the mammary gland of goats fed maize silage-based diets containing no additional oil or $6.1 \%$ of DM of sunflower-seed oil or $6.1 \%$ of DM of linseed oil. The mRNA abundance is expressed in arbitrary units determined as abundance relative to cyclophilin A mRNA and multiplied by 100 .

or activity of ACC and FAS. It is possible that differences between ruminant species are, at least in part, related to variation in the composition of the basal diet and FA content of lipid supplements. Synthesis of specific ruminal biohydrogenation intermediates known to exert antilipogenic effects might also contribute to differences in lipogenic responses between ruminant species. In the current experiment, mammary secretion of trans-9, cis-11 CLA and cis-10, trans-12 CLA, known to inhibit milk fat synthesis in the bovine (Shingfield and Griinari, 2007), was extremely low $(<3.0 \mathrm{mg} / \mathrm{d})$. Furthermore, milk fat trans-10, cis-12 CLA concentrations in treatment MSO $(0.064 \%$ of total FA; Bernard et al., 2009b) were greater compared with the amounts in milk from cows fed a comparable diet $(0.026 \%$ of total FA; Roy et al., 2006), suggesting that the antilipogenic effects of trans-10, cis-12 CLA are less potent in goats compared with cows, as would be implied from results from recent studies in the lactating caprine (Andrade and Schmidely, 2006; Lock et al., 2008; Shingfield et al., 2009).

Increases in the secretion of long-chain FA (LCFA) in response to MSO and MLO of 109 and 111\%, respectively, are in accordance with increases of between 91 and $102 \%$ in goats fed hay-based diets supplemented with plant oils or oilseeds (Bernard et al., 2005b, 2009a). However, the magnitude of increase in milk fat synthesis is substantially greater than a response of $2 \%$ in cows fed a diet comparable to the MSO treatment (Roy et al., 2006). Variation in the availability and uptake of LCFA among ruminant species could be related to species differences in the response to lipid in the diet on low fiber-high starch diets. Indirect comparisons have provided tentative evidence to indicate that the inhibitory effects of supplements containing 
trans-10, cis-12 CLA on the uptake and incorporation of LCFA differ between goats and cows (Shingfield et al., 2009). However, direct comparisons of ruminant species fed the same diet are required to confirm these considerations. Despite large increases in milk C18 FA secretion, responses to plant oils were not accompanied by elevated mammary LPL mRNA abundance and/or activity, consistent with previous studies in goats fed grass hay-based diets (Bernard et al., 2005a,b, 2009a). Decreases in mammary LPL mRNA abundance due to lipid supplements have been reported in cows fed MFD diets containing fish oil alone (Ahnadi et al., 2002) or in combination with soyabean oil (Harvatine and Bauman, 2006). Available data on gene expression suggest that mammary expression or potential activity of LPL determined in vitro are not limiting for mammary uptake of LCFA in ruminants in vivo, with the implication that other factors including substrate availability, arterial TAG concentration, and the position of LCFA in milk fat TAG (Gagliostro et al., 1991; Drackley et al., 2007) and/or mammary LPL partitioning might play a more important role. Sunflower-seed oil tended to decrease LPL activity in milk, confirming previous observations in goats, which might be explained by repartitioning of the LPL protein toward the basal membrane for very low-density lipoprotein-FA uptake at the expense of secretion via mammary epithelial cells (Chilliard et al., 2003).

An absence of altered mammary SCD mRNA abundance following the inclusion of plant oils in the diet is in line with previous studies in cows (Delbecchi et al., 2001; Peterson et al., 2003; Harvatine and Bauman, 2006) and goats (Bernard et al., 2005a, 2009a). However, mammary SCD has been reported to be downregulated by supplements of fish oil in cows (Ahnadi et al., 2002) and formaldehyde-treated linseeds in goats (Bernard et al., 2005b). It is possible that the lack of changes in goat mammary SCD mRNA abundance from linseed oil supplements on maize silage or hay-based diets (Bernard et al., 2009a) is related to the relatively low availability, incorporation, and secretion of 18:3n-3 in milk $(0.85 \mathrm{~g} / \mathrm{d}$ in the current study compared with $2 \mathrm{~g} / \mathrm{d}$ in Bernard et al., 2005b). Plant oils on a maize-based diet had no effect on mammary SCD activity, which is at odds with previous studies reporting a decrease in response to sunflower-seed oil rich in cis-9 18:1 (Bernard et al., 2005b) or 18:2n-6 (Bernard et al., 2009a) or linseed oil (Bernard et al., 2009a) in goats fed hay-based diets. This observation is even more difficult to reconcile considering the larger increases in specific CLA isomers in milk with the inclusion of plant oils in this experiment compared with those in the milk of goats fed hay-based diets (Bernard et al., 2009b). Postruminal infusion studies in cows have shown that trans-10, cis-12 CLA (Baumgard et al., 2000); trans-10, trans-12 CLA (Sæbø et al., 2005); and trans-9, trans-11 CLA (Perfield et al., 2007) reduce milk fat $\Delta^{9}$-desaturase ratios, and therefore, these biohydrogenation intermediates would be expected to be potential inhibitors of SCD activity. Peterson et al. (2004) demonstrated that trans-10, cis-12 CLA decreases lipogenesis via an inhibition of the proteolytic activation of SREBP-1, a mechanism that also involves a reduction in the transcriptional activation of lipogenic genes including SCD. Furthermore, supplements of trans-10, cis-12 CLA in the diet have been shown to decrease milk fat concentration ratios that serve as a proxy for SCD activity in goats even in the absence of significant reductions in milk fat synthesis (Andrade and Schmidely, 2006; Lock et al., 2008; Shingfield et al., 2009). Inclusion of plant oils in the diet was associated with a decrease in milk fat $\Delta^{9}$-desaturation ratios, with the magnitude of reduction being comparable to that observed in previous studies in the caprine (Bernard et al., 2009a), but these changes were not related to mammary SCD activity. However, milk fat $\Delta^{9}$-desaturase ratios might also be influenced by factors other than SCD activity, such as differential uptake, turnover, and use of substrate and product FA in mammary tissue in addition to variation in the accuracy of cis-9 containing FA determinations in milk. The current results suggest that either milk fat $\Delta^{9}$-desaturase index is also influenced by factors other than SCD activity or that potential SCD enzyme activity determined in vitro is not a true reflection of the activity in vivo, because the SCD enzyme is known to be regulated by posttraductional events and/or other cofactors. A relatively weak association $(\mathrm{r}=0.54, \mathrm{n}=14, P=0.05)$ between mammary SCD mRNA and enzyme activity determined for caprine mammary tissue in this experiment provides some indications of putative posttraductional regulatory events. Further investigations of SCD gene expression in ruminants should also be combined with direct measurements of in vivo $\Delta^{9}$-desaturation using labeled substrates to offer additional insights into the levels of regulation operating in the mammary gland for this gene.

\section{CONCLUSIONS}

Alterations in milk FA secretion in response to plant oils in the goat appeared to be regulated by mechanisms independent of changes in mammary ACC, FAS, SCD, and LPL mRNA abundance or potential lipogenic enzyme activity measured in vitro. Lipid supplements had no effect on lipogenic gene expression and/or activity in perirenal adipose or hepatic tissues, with no substantive evidence to suggest that these tissues contributed 
to the changes in milk fat secretion with lipid supplements in goats fed maize silage-based diets. Plant oils decreased milk fat $\Delta^{9}$-desaturase ratios but had no effect on mammary SCD mRNA abundance or activity. Comparisons with previous studies indicate that the proportion of starch and fiber in the diet is a major determinant of changes in SCD activity following the inclusion of plant oils in the diet, possibly mediated via the formation of specific biohydrogenation intermediates in the rumen. Results indicate that the regulation of milk fat secretion responses to plant oils in the goat occur via several mechanisms. Alterations in mammary expression of major lipogenic genes or enzymes do not appear to be the sole or main mechanism regulating milk FA secretion in the caprine, with the implication that other factors including substrate availability and/ or other metabolic pathways or genes are involved. Furthermore, current results confirm substantial differences in milk fat responses to plant oils between the goat and cow, with evidence that the lack of inhibitory effects on mammary lipogenesis in the caprine, in contrast to the bovine, are related to smaller concomitant reductions in the secretion of FA synthesized de novo and a greater output of FA derived from circulating plasma lipids.

\section{ACKNOWLEDGMENTS}

The authors acknowledge and appreciate the contribution of the staff of the UR 1213 Herbivores Unit at INRA: A. Ollier and A. Combeau for diligent care of experimental animals; R. Jailler and his team for assisting in the slaughter of experimental animals; D. Durand and P. Gaydier for the collection of mammary biopsies; and P. Capitan, C. Labonne, M. Tourret, D. Bany, and C. Faure for assistance with sample analysis.

\section{REFERENCES}

Ahnadi, C. E., N. Beswick, L. Delbecchi, J. J. Kennelly, and P. Lacasse. 2002. Addition of fish oil to diets for dairy cows. II. Effects on milk fat and gene expression of mammary lipogenic enzymes. J. Dairy Res. 69:521-531.

Ailhaud, G., F. Massiera, P. Weill, P. Legrand, J. M. Alessandri, and P. Guesnet. 2006. Temporal changes in dietary fats: Role of $n-6$ polyunsaturated fatty acids in excessive adipose tissue development and relationship to obesity. Prog. Lipid Res. 45:203-236.

Allen, M. S. 2000. Effects of diet on short-term regulation of feed intake by lactating dairy cattle. J. Dairy Sci. 83:1598-1624.

Andrade, P. V. D., and P. Schmidely. 2006. Effect of duodenal infusion of trans10,cis12-CLA on milk performance and milk fatty acid profile in dairy goats fed high or low concentrate diet in combination with rolled canola seed. Reprod. Nutr. Dev. 46:31-48.

AOAC. 1997. Official Methods of Analysis. 16th ed. AOAC, Gaithersburg, MD.

Baumgard, L. H., B. A. Corl, D. A. Dwyer, A. Sæbø, and D. E. Bauman. 2000. Identification of the conjugated linoleic acid isomer that inhibits milk fat synthesis. Am. J. Physiol. Regul. Integr. Comp. Physiol. 278:R179-R184.
Beddek, A. J., P. Rawson, L. Peng, R. Snell, K. Lehnert, H. E. Ward, and T. W. Jordan. 2008. Profiling the metabolic proteome of bovine mammary tissue. Proteomics 8:1502-1515.

Bernard, L., C. Leroux, M. Bonnet, J. Rouel, P. Martin, and Y. Chilliard. 2005a. Expression and nutritional regulation of lipogenic genes in mammary gland and adipose tissues of lactating goats. J. Dairy Res. 72:250-255.

Bernard, L., C. Leroux, and Y. Chilliard. 2008. Expression and nutritional regulation of lipogenic genes in the ruminant lactating mammary gland. Adv. Exp. Med. Biol. 606:67-108.

Bernard, L., C. Leroux, Y. Faulconnier, D. Durand, K. J. Shingfield, and Y. Chilliard. 2009a. Effect of linseed or sunflower-seed oil on milk fatty acid secretion and lipogenic gene expression in goats fed hay-based diets. J. Dairy Res. 76:241-248.

Bernard, L., J. Rouel, C. Leroux, A. Ferlay, Y. Faulconnier, P. Legrand, and Y. Chilliard. 2005b. Mammary lipid metabolism and milk fatty acid secretion in alpine goats fed vegetable lipids. J. Dairy Sci. 88:1478-1489.

Bernard, L., K. J. Shingfield, J. Rouel, A. Ferlay, and Y. Chilliard. 2009b. Effect of plant oils in the diet on performance and milk fatty acid composition in goats fed diets based on grass hay or maize silage. Br. J. Nutr. 101:213-224.

Bonnet, M., C. Leroux, Y. Faulconnier, J. F. Hocquette, F. Bocquier, P. Martin, and Y. Chilliard. 2000. Lipoprotein lipase activity and mRNA are up-regulated by refeeding in adipose tissue and cardiac muscle of sheep. J. Nutr. 130:749-756.

Cant, J. P., E. J. DePeters, and R. L. Baldwin. 1993. Mammary uptake of energy metabolites in dairy cows fed fat and its relationship to milk protein depression. J. Dairy Sci. 76:2254-2265.

Chang, J. H., D. K. Lunt, and S. B. Smith. 1992. Fatty acid composition and fatty acid elongase and stearoyl-CoA desaturase activities in tissues of steers fed high oleate sunflower seed. J. Nutr. 122:20742080.

Chilliard, Y., A. Ferlay, J. Rouel, and G. Lamberet. 2003. A review of nutritional and physiological factors affecting goat milk lipid synthesis and lipolysis. J. Dairy Sci. 86:1751-1770.

Chilliard, Y., G. Gagliostro, J. Flechet, J. Lefaivre, and I. Sebastian. 1991. Duodenal rapeseed oil infusion in early and midlactation cows. 5. Milk fatty acids and adipose tissue lipogenic activities. J. Dairy Sci. 74:1844-1854.

Chilliard, Y., F. Glasser, A. Ferlay, L. Bernard, J. Rouel, and M. Doreau. 2007. Diet, rumen biohydrogenation, and nutritional quality of cow and goat milk fat. Eur. J. Lipid Sci. Technol. 109:828-855.

Clarke, S. D. 2001. Polyunsaturated fatty acid regulation of gene transcription: A molecular mechanism to improve the metabolic syndrome. J. Nutr. 131:1129-1132.

Delbecchi, L., C. E. Ahnadi, J. J. Kennelly, and P. Lacasse. 2001. Milk fatty acid composition and mammary lipid metabolism in Holstein cows fed protected or unprotected canola seeds. J. Dairy Sci. $84: 1375-1381$.

Drackley, J. K., T. R. Overton, G. Ortiz-Gonzalez, A. D. Beaulieu, D. M. Barbano, J. M. Lynch, and E. G. Perkins. 2007. Responses to increasing amounts of high-oleic sunflower fatty acids infused into the abomasum of lactating dairy cows. J. Dairy Sci. 90:51655175 .

Faulconnier, Y., M. Thevenet, J. Fléchet, and Y. Chilliard. 1994. Lipoprotein lipase and metabolic activities in incubated bovine adipose tissue explants: Effects of insulin, dexamethasone, and fetal bovine serum. J. Anim. Sci. 72:184-191.

Gagliostro, G., and Y. Chilliard. 1991. Duodenal rapeseed oil infusion in early and midlactation cows. 2. Voluntary intake, milk production, and composition. J. Dairy Sci. 74:499-509.

Gagliostro, G., Y. Chilliard, and M. J. Davicco. 1991. Duodenal rapeseed oil infusion in early and midlactation cows. 3. Plasma hormones and mammary apparent uptake of metabolites. J. Dairy Sci. 74:1893-1903.

Harrison, J. H., R. L. Kincaid, J. P. McNamara, S. Waltner, K. A Loney, R. E. Riley, and J. D. Cronrath. 1995. Effect of whole cottonseeds and calcium salts of long-chain fatty acids on performance of lactating dairy cows. J. Dairy Sci. 78:181-193. 
Harvatine, K. J., and D. E. Bauman. 2006. SREBP1 and thyroid hormone responsive spot 14 (S14) are involved in the regulation of bovine mammary lipid synthesis during diet-induced milk fat depression and treatment with CLA. J. Nutr. 136:2468-2474.

INRA. 1989. Ruminant nutrition. Pages 15-21 in Recommended Allowance and Feed Table. R. Jarrige, ed. INRA, Paris, France.

Lock, A. L., M. Rovai, T. A. Gipson, M. J. de Veth, and D. E. Bauman. 2008. A conjugated linoleic acid supplement containing trans-10, cis-12 conjugated linoleic acid reduces milk fat synthesis in lactating goats. J. Dairy Sci. 91:3291-3299.

Loor, J. J., A. Ferlay, A. Ollier, M. Doreau, and Y. Chilliard. 2005. Relationship among trans and conjugated fatty acids and bovine milk fat yield due to dietary concentrate and linseed oil. J. Dairy Sci. 88:726-740.

Mathieu, L., and L. Ferré. 1914. Caractérisation du mouillage des laits par une constante de concentration moléculaire. Ann. Falsif. Fraud. 5:12.

McNamara, J. P., J. H. Harrison, R. L. Kincaid, and S. S. Waltner. 1995. Lipid metabolism in adipose tissue of cows fed high fat diets during lactation. J. Dairy Sci. 78:2782-2796.

Parodi, P. W. 2005. Dairy product consumption and the risk of breast cancer. J. Am. Coll. Nutr. 24:556S-568S.

Perfield, J. W. II, A. L. Lock, J. M. Griinari, A. Sæbø, P. Delmonte, D. A. Dwyer, and D. E. Bauman. 2007. Trans-9, cis-11 conjugated linoleic acid reduces milk fat synthesis in lactating dairy cows. J. Dairy Sci. 90:2211-2218.

Peterson, D. G., E. A. Matitashvili, and D. E. Bauman. 2003. Dietinduced milk fat depression in dairy cows results in increased trans-10, cis-12 CLA in milk fat and coordinate suppression of mRNA abundance for mammary enzymes involved in milk fat synthesis. J. Nutr. 133:3098-3102.

Peterson, D. G., E. A. Matitashvili, and D. E. Bauman. 2004. The inhibitory effect of trans-10, cis-12 CLA on lipid synthesis in bovine mammary epithelial cells involves reduced proteolytic activation of the transcription factor SREBP-1. J. Nutr. 134:2523-2527.

Piperova, L. S., B. B. Teter, I. Bruckental, J. Sampugna, S. E. Mills, M. P. Yurawecz, J. Fritsche, K. Ku, and R. A. Erdman. 2000. Mammary lipogenic enzyme activity, trans fatty acids and conjugated linoleic acids are altered in lactating dairy cows fed a milk fat- depressing diet. J. Nutr. 130:2568-2574.
Roy, A., A. Ferlay, K. J. Shingfield, and Y. Chilliard. 2006. Examination of the persistency of milk fatty acid composition responses to plant oils in cows fed different basal diets, with particular emphasis on trans $-\mathrm{C}_{18 \cdot 1}$ fatty acids and isomers of conjugated linoleic acid. Anim. Sci. 82:479-492.

Sæbø, A., P. C. Sæbø, J. M. Griinari, and K. J. Shingfield. 2005. Effect of abomasal infusions of geometric isomers of 10,12 conjugated linoleic acid on milk fat synthesis in dairy cows. Lipids 40:823832.

Shingfield, K. J., Y. Chilliard, V. Toivonen, P. Kairenius, and D. I. Givens. 2008. Trans fatty acids and bioactive lipids in ruminant milk. Adv. Exp. Med. Biol. 606:3-65.

Shingfield, K. J., and J. M. Griinari. 2007. Role of biohydrogenation intermediates in milk fat depression. Eur. J. Lipid Sci. Technol. 109:799-816.

Shingfield, K. J., J. Rouel, and Y. Chilliard. 2009. Effect of calcium salts of a mixture of conjugated linoleic acids containing trans-10, cis-12 in the diet on milk fat synthesis in goats. Br. J. Nutr. 101:1006-1019.

Sumner, J. M. C. Shachtschneider, J. Vierck, and J. P. McNamara 2007. Changes in the transcriptome of adipose tissue of the dairy heifer during late pregnancy and lactation as measured by gene array analysis: Changes in specific metabolic control genes. J. Dairy Sci. 91(E-Suppl. 1):313. (Abstr.)

Vernon, R. G. 1980. Lipid metabolism in the adipose tissue of ruminant animals. Prog. Lipid Res. 19:23-106.

Vernon, R. G., A. Faulkner, E. Finley, H. Pollock, and E. Taylor. 1987. Enzymes of glucose and fatty acid metabolism of liver, kidney skeletal muscle, adipose tissue and mammary gland of lactating and non-lactating sheep. J. Anim. Sci. 64:1395-1411.

Wahle, K. W., S. D. Heys, and D. Rotondo. 2004. Conjugated linoleic acids: Are they beneficial or detrimental to health? Prog. Lipid Res. 43:553-587.

Ward, R. J., M. T. Travers, S. E. Richards, R. G. Vernon, A. M. Salter, P. J. Buttery, and M. C. Barber. 1998. Stearoyl-CoA desaturase mRNA is transcribed from a single gene in the ovine genome. Biochim. Biophys. Acta 1391:145-156. 